\title{
A Change in Attitude
}

Tucson, Ariz., is a great place to live! The climate and environment encourages outdoor entertaining in settings such as depicted on the front cover virtually all year round, but water is a major concern. Prior to 1974, Tucsonans' attitudes towards water use were typical for the desert Southwest. Although conscious of a limited groundwater supply and no surface water sources, people and institutions tended to maintain rather lush landscapes. However, that summer was one of the hottest and driest on record. Wells were incapable of consistently meeting prolonged peak demands, resulting in local service disruptions and chronic low water pressure. Faced with a declining groundwater level, continued population growth, and expensive capital improvements, the city water utility decided to make a serious effort to encourage water conservation. Initially, water rates were increased $30 \%$. Additional, if less dramatic, increases were imposed in subsequent years, along with the adoption of a progressive rate structure (cost of water rises with increased use). The utility also initiated an educational program designed to reduce capital improvement costs. This program, known as "Beat the Peak", encouraged water efficiency in residential landscape maintenance, thereby re ducing peak demands during the summer.

In 1980, the state legislature established the Arizona Groundwater Management Code, recognized as the most comprehensive groundwater law in the nation and named as one of the 10 most innovative programs in state and local government by the Ford Foundation. A major goal of the code with respect to Tucson is eliminating overdraft by 2025 . This goal is to be met through augmentation of water supplies and conservation. A principal source of supply augmentation will be the Central Arizona Project (CAP). This 530$\mathrm{km}$ canal is expected to be complete in 1991, and will deliver an average of 1.5 $\mathrm{km}^{3}$ of water annually to Phoenix, Tucson, and intermediate areas from the Colorado River on the state's western boundary. The water is not intended to increase overall usage, but to serve as a substitute for groundwater. Indeed, state and federal statutes provide that CAP water will be used to

Front cover: Desert plants incorporated into a patio design. Photograph by Ted Bundy. reduce groundwater overdraft by one-half to two-thirds.

Although some steps in supply augmentation have been taken, such as using effluent to irrigate golf courses, it is the conservation aspects of the Groundwater Management Code that have had the most immediate impact. The code restricts the size and number of swimming pools for residences, resorts, motels, and country clubs. It requires developers to demonstrate a 100-year supply of good-quality water before land can be marketed to the public, and restricts the annual water application rate for large turf areas such as golf courses, schools, parks, and cemeteries. The code also mandates the use of low-water-requiring plants along public right-of-ways, which increased the visibility of drought adapted trees, shrubs, and wildflowers. As a result, people realized that they did not have to resort to cacti and succulents to have a water-conserving landscape. The Arizona nursery industry, with a strong tradition of plant introduction, responded, and the palette of available plant material changed dramatically. Some of the more popular drought-adapted trees and shrubs are Acacia smallii (southwestern sweet acacia), Caesalpinia pulcherrima (red bird of paradise), Cassia artemisioides (feathery cassia), Cercidium sp. (four species of palo Verde), Leucophyllum frutescens (Texas ranger), Prosopis sp. (a thornless South American mesquite hybrid), and Sophora secundiflora Texas mountain laurel). Plants from the local desert or from deserts in Australia, Mexico, and Texas are continuing to be introduced.

The Southern Arizona Water Resources Association (SAWARA), along with the Tucson water utility, has been most active in promoting water conservation.
SAWARA has adopted and aggressively promoted the seven xeriscape concepts: water-conserving design, low -water-use/ drought-tolerant plants, turf reduction, water harvesting, appropriate irrigation methods, soil improvement and mulch, and proper maintenance. Since $\approx 45 \%$ of water consumed by the average household is used for landscape irrigation, even modest reductions in landscape water requirements would significantly affect total consumption. SAWARA also conducts an annual xeriscape contest and conference for professionals in landscape design, installation, and maintenance. The result of the rate increases and conservation promotion has been the development of a water conservation ethic that is reflected in Tucson landscapes and lifestyles. As an example, Tucson Water recently offered a rebate for conversion to low-flush toilets in existing homes. Similar programs have been largely unsuccessful in other communities, but the response in Tucson threatened to deplete allocated funds before the designated time period was half over. Per-capita water consumption has declined from an average of 700 liter.day ${ }^{-1}$ during 1969-1976 to al most 600 liter $\cdot$ day $^{-1}$ in 1989 , despite a growing city population. Many residences do not have turf in the front landscape, and a large percentage have no turf at all. Indeed, golf courses, commercial institutions, and government agencies are routinely criticized when the public perceives that they are devoting too much area to turf.

The evolving sensitivity to water is altering Tucson's appearance, but it may not be obvious unless you escape the downtown environs. We encourage you to tour the city and witness the differences a change in attitude have made.

JIMMY L. TIPION Extension Horticulturist Dept. of Plant Sciences Univ. of Arizona Tucson, AZ 85721 